\title{
Who breaks a butterfly upon a wheel? Animals in art and morality in copyright
}

Satire or sense, alas! can Sporus feel?

Who breaks a butterfly upon a wheel?

Alexander Pope, Epistle to Dr Arbuthnot, 1735

\begin{abstract}
Alexander Pope's satirical poem, Epistle to Dr Arbuthnot, produced a popular phrase to distinguish 'overkill', as it were - that is, where one exercises a surfeit of effort for a very minor objective. The saying, 'to break a butterfly upon a wheel', thus introduces the question of balance, a kind of ethical weighing of harms and benefits that is understood, rightly or wrongly, to characterize intellectual property as well as most utilitarian approaches to animal welfare.

Damien Hirst's recent exhibition at White Cube in London provoked an unusual if not new perspective upon the question of appropriation in art. The exhibit included several new paintings created out of thousands and thousands of butterfly wings. One reviewer describes it thus: 'Appropriation becomes ecstasy'. ${ }^{1}$ But what does it mean to identify the exploitation of animals in art as 'appropriation'?

Hirst has been creating these so-called Kaleidoscope paintings since 2001, but his use of butterflies goes back to the 1991 In and Out of Love exhibit in London. The installation comprised two works. The downstairs space, In and Out of Love (White Paintings and Live Butterflies), presented large white canvasses to which Hirst glued butterfly pupae on the verge of hatching. During the exhibition butterflies were said to have emerged from the canvasses to feed on flowers and sugar water, fly about, reproduce and eventually die; although it is not entirely clear the extent to which this cycle was achieved. When the exhibit was reproduced for Tate Modern in 2012, the security guard told one reviewer that the live butterflies were actually brought in each day. ${ }^{2}$

The second installation, in the upstairs space, was In and Out of Love (Butterfly Paintings and Ashtrays). This installation was comprised of the first of Hirst's butterfly monochrome paintings using butterflies and household paint, together with four glass ashtrays filled with cigarette butts.

Since these early exploitations of butterflies in his works, Hirst has gone on to produce several series of Kaleidoscope paintings, beginning with It's a Wonderful World (2001) where Hirst arranged thousands of colourful butterfly wings into household paint in order to create various concentric patterns. The Kaleidoscope paintings were first exhibited at White Cube in 2003. And in his recent exhibition of new work at White Cube, Mandalas, Hirst presented several new Kaleidoscope paintings.
\end{abstract}

1. J Jones, 'Damien Hirst Flutters Round the Cosmos on Butterfly Wings - Mandalas Review', The Guardian, 19 September 2019.

2. P Barkham, 'Damien Hirst's Butterflies: Distressing but Weirdly Uplifting', The Guardian, 18 April 2012. The guard told Barkham that the live butterflies were brought in every day by Luke Brown of the Natural History Museum's butterfly house. 
In his review of Mandalas for The Guardian newspaper, Jonathan Jones describes the use of animals in Hirst's art as a kind of 'worship'. ${ }^{3}$ This description is not unexpected given the religious theme of the exhibition (apart from the title of the exhibition itself, Mandalas, the works included, for example, the Kaleidoscope painting, Diety, exhibited alongside the triptych, The Creator). But it is nevertheless still intriguing, for several reasons, that this appropriation of animals is viewed as worship. First, there is an ancient relationship between humans and other animals expressed through art and ritual, including sacrifice, and animals were and continue to be significant figures of worship in the original meaning of anthropomorphism. Secondly, the ancient development of the earliest kinds of property systems was closely linked to the domestication of animals and the development of agriculturalism. And finally, animals are themselves configured as property, while at the same time challenging the notion of property through the interaction with other legal relationships, including welfare laws. Indeed, in response to the 2012 Tate show, the chief executive of Butterfly Conservation, Martin Warren, specifically referred to the treatment of the butterflies as disposable property: 'It is very sad to hear of the death of so many butterflies. Butterfly Conservation is concerned that this work represents a throwaway approach to living creatures and encourages a lack of respect for the environment.' 4

Indeed, when it comes to the relationship between humans and all other animals, the connection to worship and sacrifice is an ancient one, and it is one that is invariably interconnected with domestication and the development of agriculturalism, ${ }^{5}$ and, as such, with the development of property. Jones defends Hirst's use of the butterflies by comparing it to their use in science, referring to the millions of animal specimens in the Natural History Museum. The other common defence is one that is recognized in many areas of animal use and is articulated quite clearly around the notion of the animal as property, as 'found object' - that the butterfly species used are common species and that they are produced for use by humans. ${ }^{6}$ In response to the question, 'Is it cruel?' Patrick Barkham, betraying somewhat of a disconnection from the welfare question itself, provides the curious answer that the butterflies are common tropical species and farmed for such use. ${ }^{7}$ In other words, his answer seems concerned more with the notion of the butterfly as property and the risk of waste (common species are thus presented as disposable), rather than the question of cruelty. Then, in somewhat of an appeal to a tu quoque fallacy (or as one letter writer describes it, "whataboutery'), ${ }^{8}$ Barkham argues that such use is 'at least no more cruel than farming

\section{Jones (n 1).}

4. Martin Warren quoted in R Nikkhah, 'Damien Hirst Condemned for Killing 9,000 Butterflies in Tate Show', The Telegraph, 14 October 2012.

5. JZ Smith, Relating Religion: Essays in the Study of Religion (University of Chicago Press, Chicago 2004) 149. Smith goes on to consider, however, the way in which the management of domesticated animals includes killing or containment practices (selective breeding, culling, etc.), and argues that 'it does appear that the other elements characteristic of domestication have their concomitant elaborations in sacrifice' (152).

6. Barkham (n 2).

7. A spokesman for Tate Modern in response to criticism of the 2012 exhibit made a similar argument: 'The butterflies used in this [Hirst] work were all sourced from reputable UK butterfly houses and were selected from varieties known to thrive in the conditions created.' Quoted in Nikkhah (n 4).

8. Trevor Moore, 'Awed by Butterflies, But Not by Damien Hirst's Art', The Guardian, 22 September 2019. 
pigs in a barn with plenty of straw'. ${ }^{9}$ In this way, the appropriation of butterflies for art as worship becomes a kind of worship of property. And what could be more endemic in the controversies surrounding contemporary art collecting than that?

Hirst's use of living butterflies in his installations has not gone without serious criticism. The 2012 exhibit at Tate Modern (where fresh living butterflies were delivered each day) attracted the attention of the RSPCA:

In this so-called 'art exhibition', butterflies are forced to exist in the artificial environment of a closed room for their entire lives. There would be a national outcry if the exhibition involved any other animal, such as a dog. Just because it is butterflies, that does not mean they do not deserve to be treated with kindness. ${ }^{10}$

Indeed, Hirst's appropriation of animal lives in the production of his art raises some urgent questions. Caroline Goldstein estimates that almost one million animals have perished in the name of art through Hirst's works. She asks, 'But what of the animals who laid down their lives for the privilege of partaking in Hirst's grand conceit?'11 What indeed?

But this question of the use of animals in art is an important one, not only for the industry but also for the ethical context in which copyright might be enjoyed more generally. Indeed, this kind of ethical inquiry is not unfamiliar to protection frameworks in other areas of intellectual property. So is it time for such a relationship between ethics and copyright to become clearer?

In this respect, does the business model of Hirst's 'appropriations' provide insight into appropriation art more generally? The question of originality and value is often a complex one. Does art need to be original? Is art creative? Or is it social in the same sense in which value is 'trafficked' through social media, as it were? Does some art simply put a price on scandal? And what does copyright have to do with this question?

Paul Ingram of Columbia Business School recently collaborated with Mitali Banerjee of HEC Paris in order to investigate the makings of value in art markets. ${ }^{12}$ Drawing upon the findings and data of MoMA curator, Leah Dickerman, the authors quantified various indicators of fame, which they distinguish from related constructs such as reputation and status, in order to understand the way in which the artists' social networks influenced the value of their work. They discovered that the most critical factor for achieving fame was not creativity or even expert acclaim, but rather that particular artist's social network. In this way, notoriety may become a more relevant indicator of success than creativity. In social media, where traffic becomes the only marker of 'value', scandal emerges as a tool for fame. The effect of this on the welfare of humans and other animals appropriated (or indeed exploited) for such 'works' is thus an urgent consideration.

Does notoriety thus become not only an incentive for creativity, but also the only criterion for ethical and social risks, such as those that might arise in Hirst's works? In an age when even governments are governing by scandal, what might copyright have to do with the ethics of art?

On one level, copyright becomes implicated in an economy of scandal, a value in and of itself with which to court notoriety. The appropriation artist, Richard Prince, is

\section{Barkham (n 2).}

10. RSPCA spokesman quoted in Nikkhah (n 4).

11. C Goldstein, 'How Many Animals Have Died for Damien Hirst's Art to Live? We Counted', ArtNet News, 13 April 2017.

12. M Banerjee and PL Ingram (2018) Fame as an Illusion of Creativity: Evidence from the Pioneers of Abstract Art, HEC Research Papers Series 1305, HEC Paris. 
no stranger to copyright litigation, his work having incited disputes on repeated occasions. ${ }^{13}$ In this context, copyright as a value in and of itself is largely seen as a tool for conflict, rather than enforcement. As one critic notes:

I'm not even sure Prince truly cares about winning this lawsuit. He may simply be pushing the boundaries to see what he can get away with. He seems to be baiting photographers into suing him and he may keep going until a court finally tells him he's hit the limit ... Copyright infringement suits make the news, raising Prince's profile as an appropriation artist and drawing more attention to his work, so this may be another (high priced) attempt to gain more publicity. ${ }^{14}$

Where the industry itself is expanding into a global market in celebrity, ${ }^{15}$ understanding the relationship between value, ethics, publicity and social networks is crucial.

But what if the relational nature of copyright were to be more effectively imbued with an ethical accountability to the 'properties' it purportedly regulates? Throughout intellectual property there are examples of the way in which the system embodies the mutual relations inherent in any form of property, including intellectual property. In other words, intellectual property is not a one-sided relationship between the 'object' and the creator, but a relation between creator and audience.

This is very clear in patent law where immoral inventions are precluded from protection. And where immorality comes into conflict with other interests, a balance is drawn between the benefit and the harm. Indeed, with specific relevance to the present case of the butterflies, patent law requires a line to be drawn between animal suffering and their usefulness to human animals. ${ }^{16}$ Trade mark law also excludes immoral trade marks from registration. ${ }^{17}$ And in design law, there is similarly a prohibition on rights subsisting in designs where they are contrary to principles of morality. ${ }^{18}$ Copyright is a slightly more uncertain area. In the UK, the English courts have refused protection for works identified as immoral. ${ }^{19}$ However, this approach may have been overtaken by EU law. ${ }^{20}$ In copyright, at least, unlike the accountability in other areas of intellectual property, the truly relational nature of property is made much less clear. Copyright, for all intents and purposes, is rather one-sided.

Does copyright need more accountability not only to the creator, but also to the audience? Does copyright similarly need to engage in a more relational way between users, as it were, rather than upon objects? In this way, extreme examples of animal cruelty and exploitation could not lead to copyright and the rich markets in the reproduction of those

13. Cariou v Prince, 714 F.3d 694 (2d Cir. 2013); Graham v Prince, 265 F.Supp.3d 366 (SDNY 2017).

14. KL Cox, 'Richard Prince: Thief, Appropriation Artist, or Performance Artist?', Above the Law, 18 October 2018.

15. R Wetzler, 'How Modern Art Serves the Rich', New Republic, 26 February 2018.

16. T 19/90 Onco-mouse/Harvard [1990] OJ EPO 476 at [r.5]; see further Directive 98/44/EC Article 6(2)(d) and European Patent Convention, article 53(a).

17. Regulation (EU) No 2017/1001 on the European Union trade mark, article 7(1)(f); Directive (EU) 2015/2436 to approximate the law of the Member States relating to trade marks, article 4(1)(f).

18. Regulation (EC) No 6/2002 on Community design, article 9; Directive 98/71/EC on the legal protection of designs, article 8 .

19. Glyn v Weston Feature Film Co [1916] 1 Ch 261; A-G v Guardian Newspapers Ltd (Spycatcher), [1990] 1 AC 109 at 294. See further J Phillips, 'Copyright in Obscene Works: Some British and American Problems' (1977) 6 Anglo-American Law Review 138.

20. A Speck et al., Laddie, Prescott and Vitoria: The Modern Law of Copyright (4th edn, Lexis Nexis, London 2018) at [21.28]. 
works in other commercial products. Potentially, and perhaps even more importantly, the creator could thus not enjoy moral rights in such an expression. This is not to reconfigure copyright as a tool of censorship, but rather as a welfare mechanism. The battle cry of freedom of expression cannot be made to trump the suffering of sentient animals. Not only does such use have an immediate and direct impact upon the animals themselves, but also there is a wider consideration for the way in which cruelty is normalised in the name of art.

In this context, Edward Lucie-Smith returns us to the question of sacrifice in another review of the Mandalas exhibition:

Is [Hirst] entitled to sacrifice so many fragile beautiful creatures to ram home this lesson? That's for you, and not me, to say. What I can say is that this is Hirst's most striking series for quite a long time. If you find it uncomfortable to contemplate, that may indeed be part of its intention. ${ }^{21}$

Once again, the artist's intention is presented as a foil to the cruelty of the use. In conversation with Will Self, Hirst famously said, 'It's ridiculous what I do. I can't believe in it - but I have to. ${ }^{22}$ These words are not only commercially savvy but also a betrayal of the awareness that in order to court scandal, one must be ready with a message, the weight of artistic intent. Indeed, in a flourish of deference to authorial intent, Jonathan Jones asks just this question as a kind of answer, as it were, to Hirst's use of animals, obscuring that intent in a history of sacrifice and the worship of property: 'What does [Hirst] believe in? Can he say? But he has to worship. ${ }^{23}$

Copyright may have nothing to say about the message, but it can begin to account for the execution. So to speak.

It seems that in his concentric patterns of the parts of butterflies, Hirst's Kaleidoscopes are perhaps almost a literal representation of breaking a butterfly upon a wheel.

Overkill, as it were. Overkill indeed.

Johanna Gibson

July 2019

21. E Lucie-Smith, 'Damien Hirst Butterfly Genocide', Artlyst, 22 September 2019.

22. Damien Hirst quoted in W Self, Junk Mail (Bloomsbury, London 2006) 310.

23. Jones (n 1). 